\title{
MORPHOLOGICAL CHARACTERIZATION OF Kielmeyera coriacea Mart. CORK FROM BRAZILIAN CERRADO
}

\author{
Polliana D`Angelo Rios ${ }^{1}$, Fábio Akira Mori², Ana Carolina Maioli Campos Barbosa ${ }^{3}$
}

(received: March 22, 2010; accepted: May 27, 2011)

\begin{abstract}
Kielmeyera coriacea Mart., known as "pau-santo", is mentioned in the literature as the main tree species which produces cork of the Brazilian Cerrado. The purpose of this study was to describe the morphological aspect of Kielmeyera coriacea ("pau-santo") cork cells through its microscopic structure and to compare it with the cellular morphology of Quercus suber (cork oak), which is the main cork producing species worldwide. The bark from three trees of the species Kielmeyera coriacea Mart. was collected randomly at points $1.30 \mathrm{~m}$ above the ground, with four repetitions per sample. Samples came from native stands situated in the region of Luminárias - MG, Brazil. The study of morphological characteristics was conducted by counting the number of sides of the cells, and measuring the dimensions of the cells from images obtained by scanning electron microscopy (SEM). Images were analyzed using the LEOUIF software. The distribution in faces and edges of cork cells from Kielmeyera coriacea, was observed to have from 4 to 8 sides, with a predominance of hexagonal cells, similar to Quercus suber. The averages of height and thickness of the cell walls were 40 to $70 \mu \mathrm{m}$ and 1.5 to $2.0 \mu \mathrm{m}$ respectively, indicating cells from an early growth season. Both height and thickness were observed to be greater than those present in Quercus suber.
\end{abstract}

Key words: Anatomy, scanning electron microscopy, morphology, non-timber forest products, distribution function.

\section{CARACTERIZAÇÃO MORFOLÓGICA DA CORTIÇA DE Kielmeyera coriacea Mart. DO CERRADO BRASILEIRO}

RESUMO: A Kielmeyera coriacea Mart., conhecida popularmente como "pau-santo", é mencionada na literatura como principal espécie arbórea do Cerrado brasileiro produtora de cortiça. Conduziu-se este trabalho, com o objetivo de descrever o aspecto morfológico das células da cortiça de Kielmeyera coriacea (pau-santo), por meio da estrutura microscópica e comparar com a morfologia celular do Quercus suber (sobreiro), a principal espécie mundial produtora de cortiça. Foram coletadas, aleatoriamente, cortiça de 3 árvores, na posição do diâmetro a 1,30 m do solo, com 4 repetições por amostra, provenientes de povoamentos nativos, localizados no município de Luminárias - MG, Brasil. O estudo das características morfológicas foi realizado pela contagem dos lados e de mensurações das células, utilizando o software LEOUIF nas imagens obtidas em microscópio eletrônico de varredura (MEV). As células de cortiça da Kielmeyera coriacea Mart., em relação à distribuição de poligonidade, apresentaram 4; 5; 6; 7 e 8 lados, com predominância de células hexagonais, similares as da espécie de Quercus suber. A altura e espessura médias das paredes das células foi de 40 a $70 \mu \mathrm{m}$ e 1,5 a 2,0 $\mu \mathrm{m}$, respectivamente, este último indicando células de início de estação. Tanto a altura quanto a espessura médias foram superiores quando comparadas ao Quercus suber.

Palavras-chave: Anatomia, microscopia eletrônica de varredura, produtos florestais não-madeireiros, distribuição de polígonos.

\section{INTRODUCTION}

The Cerrado is the regional name given to the Brazilian ecosystem similar to the savanna, and it is characterized by different regions defined by water availability, soil conditions and fire regimes. Several species present in the Cerrado are sources of Non-Wood Forest Products and are part of an important market in Brazil. More than 20 species adapted to the ecological conditions present in the Cerrado could be promising for the production of cork tissue (suber); however, due to the lack of knowledge of the cork from these species, Brazil continues to be dependent on the import of this important raw material for processing and marketing.

Among the various species that comprise the natural vegetation in Brazil, Kielmeyera coriacea, known as "pausanto", belongs to the family Guttiferae and is mentioned in the literature as the main cork producing tree species from the Cerrado (DIONELLO; BASTA, 1980). The Kielmeyera Mart. is an endemic genus from South America, comprised of approximately 47 species, of which 45 are native from Brazil (RIZZINI; HERING, 1962). Although species of

\footnotetext{
${ }^{1}$ Forest Engineer, DSc. in Wood Science and Technology - Universidade Federal de Lavras/ UFLA - Cx. P. 3037 - 37200-000 - Lavras, MG, Brasil pollyrios@uol.com.br

${ }^{2}$ Forest Engineer, Professor, DSc. in Forest Science - Departamento de Ciências Florestais - Universidade Federal de Lavras/UFLA - Cx. P. 3037 37200-000 - Lavras, MG, Brasil - morif@dcf.ufla.br

${ }^{3}$ Forest Engineer, Professor, DSc. in Forest Engineering - Departamento de Ciências Florestais - Universidade Federal de Lavras/UFLA - Cx. P. 3037 37200-000 - Lavras, MG, Brasil - accampos@gmail.com
}

Cerne, Lavras, v. 17, n. 3, p. 387-392, jul./set. 2011 
Kielmeyera are massively concentrated in Central Brazil (GRAMACHO, 1997), the genus' geographical distribution includes all five Brazilian regions; nevertheless, few species are present in the North and South regions.

"Pau-santo" could potentially be used as a source of cork due to the abundance and accessibility of the plant, which presents a high yield of cork production. The cork tissue is characterized as being lightweight and easily detached from the tree trunk. The first cork layer can be removed from the tree at an age of five to six years, when the trees are approximately 15 to $20 \mathrm{~cm}$ in diameter. Successive cork layers can be harvested at five to six-year rotations due to a high regeneration capacity (LIMA; MARCATI, 1989; SOUZA, 1974). The cork tissue can reach a mean value of $54 \%$ of the stem volume, depending on the geographic location (site conditions), and the size class of the tree (FERREIRA, 1974). Despite earlier studies of Kielmeyera coriacea, many aspects relating to the cellular structure of the cork remain unknown.

Currently, the main cork supplying plant in the world is the Quercus suber (cork oak), which is considered the best cork in the world (AGRO.GES, 2000). The cells are described in the literature as being hexagonal, closed units filled with air, regularly arranged without intercellular spaces (PEREIRA et al., 1987). This structure is important for technological properties such as weight, mechanical strength, thermal insulation, imperviousness to liquids, and acoustics among others (FORTES et al., 2004; NATIVIDADE, 1950).

This study aims to describe the morphological aspect of cork cells of Kielmeyera coriacea through its microscopic structure and compare this to the cellular morphology of Quercus suber.

\section{MATERIAL AND METHODS}

2.1 Sampling and specimen preparation for scanning electron microscope (SEM)

Cork samples were obtained randomly from three trees from natural stands located in the city of Luminárias, Minas Gerais State, Brazil (21 31' 33 89' S, 44 52' 53 54 " W, altitude $1190 \mathrm{~m}$ ). Cork tissue was cut at breast height $(1.3 \mathrm{~m})$, with four repetitions per sample (tree).

All samples were immersed in Karnovisk's modified fixative solution with a $\mathrm{pH}$ of 7.2 for a 24 hours period, and then transferred into a cryo-protective liquid (30\% glycerol) for 30 minutes. Specimens were than cut with razor blades in transversal and longitudinal directions in liquid nitrogen to be approximately $1 \times 1 \times 1 \mathrm{~cm}$.

Cerne, Lavras, v. 17, n. 3, p. 387-392, jul./set. 2011
The sections obtained were transferred to a $1 \%$ osmium tetroxide $\left(\mathrm{OsO}_{4}\right)$ solution for 1 hour and subsequently dehydrated in an ascending series of acetone baths $(30,50,70,90$ and $100 \%)$ and taken to the drier until critical point was achieved.

The specimen sections were mounted on aluminum stubs with the aid of double faced carbon tape. Once assembled, the stubs were taken to Sputtering for surface coating with gold ( $200 \AA$ in thickness) to increase the specimens' resistance and conductivity.

The samples were observed using a scanning electron microscope, model LEO EVO 40XVP. Several images per specimen were produced and digitally recorded at different magnifications at $20 \mathrm{kV}$ EHT (extra high tension) and a working distance of $9 \mathrm{~mm}$.

\subsection{Cellular structure analysis}

The distribution function of cell sides, i.e. the number of sides (vertices) of the cells of a particular section (tangential or non-tangential), were determined by the fraction $f_{i}$ of $i$-sided cells (polygons), defined by:

$$
f_{i}=\frac{N_{i}}{\sum N_{i}}
$$

where $N_{i}$ represents the number of cells with $i$ sides, and $\Sigma N_{i}$ the total number of cells. Therefore:

$$
\sum f_{i}=1
$$

A parameter to measure the topological disorder of a two-dimensional network (dispersion of $i$ around the average six) was defined by the following equation, according to Fortes et al. (2004):

$$
\mu_{2}=S(i-6)^{2} f_{i}
$$

whereby:

$f_{i}=$ fraction of $\mathrm{i}$-sided polygons

$i=$ number of sides

The cell measurements were acquired using the LEOUIF software to analyze the SEM captured images. Forty measurements of the cell cavities height and cellular wall thickness were performed for each section.

\section{RESULTS AND DISCUSSION}

Figure 1 presents the main anatomical sections of Kielmeyera coriacea Mart. cork obtained from SEM images. 

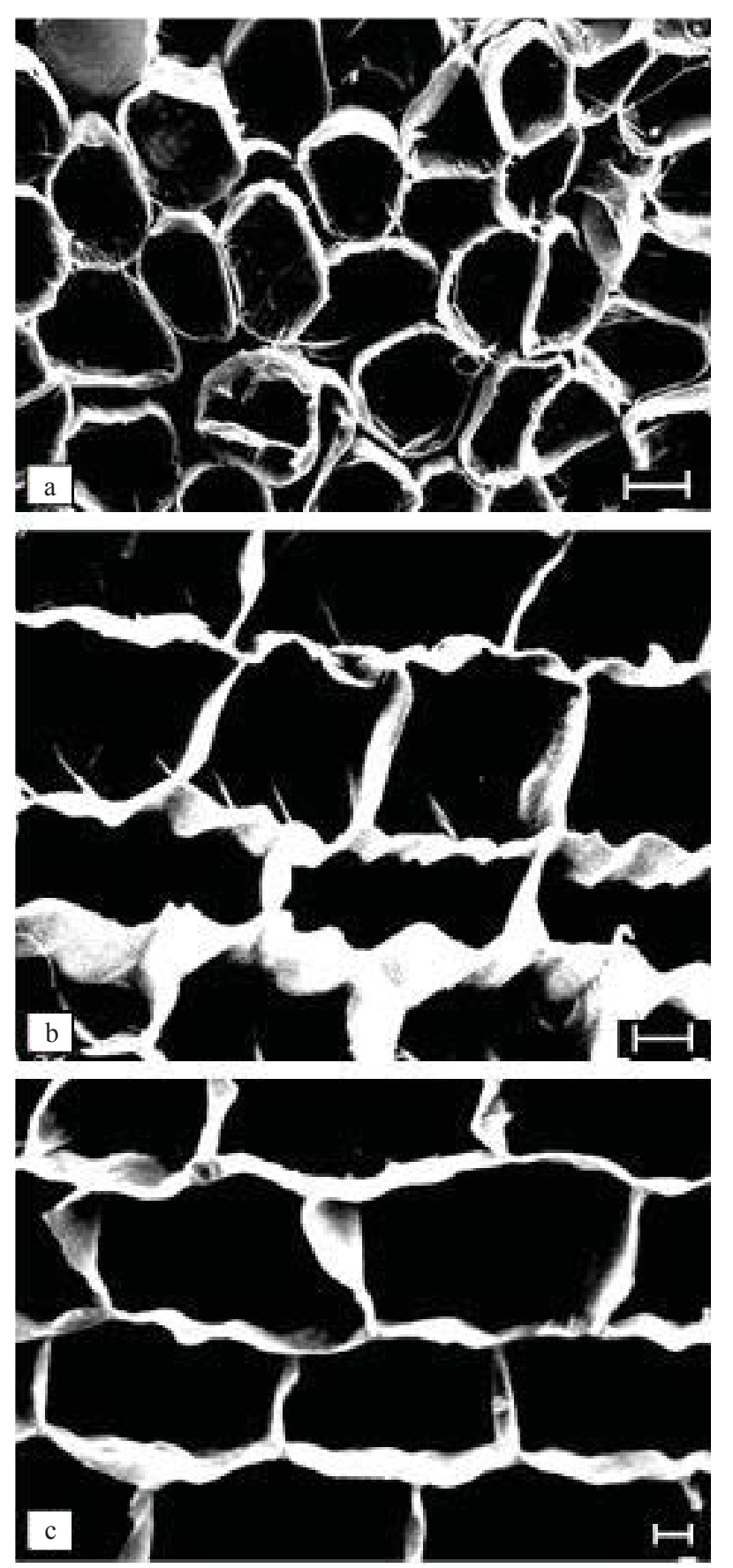

Figure 1 - General structure of Kielmeyera coriacea Mart. cork sections: (a) tangential section, (b) cross-section, (c) radial section. Scales: (a) $20 \mu \mathrm{m}$, (b) $100 \mu \mathrm{m}$, (c) $20 \mu \mathrm{m}$.

Figura 1 - Estrutura geral das seções da cortiça de Kielmeyera coriacea Mart.: (a) seção tangencial, (b) seção transversal, (c) seção radial. Escalas: (a) $20 \mu \mathrm{m}$, (b) $100 \mu \mathrm{m}$, (c) $20 \mu \mathrm{m}$.
The first cork layer produced by the original phellogen is named 'virgin cork' and, for Quercus suber is considered to be of poor quality. Good quality cork is obtained from the successive layers after the removal of the second cork harvest, and is known as 'reproduction cork' (PEREIRA et al., 1987), which is harvested at nineyear intervals. The Kielmeyera coriacea Mart. cork was extracted from trees that had never undergone cork removal ('virgin cork'), and when compared to the Quercus suber cork obtained from third extraction ('reproduction cork'), the images are strikingly similar in structure (FORTES et al., 2004; PEREIRA et al., 1987).

Figure 1a shows the honeycomb-like arrangement (polygonal form) of the tangential surface from the cork cells. For technological application of the cork, the number of sides (or neighboring cells) of each cell is an important property of the cork tissue, and determines the cork's performance in waterproofing, sound insulation, mechanical strength, among other applications.

Figure $1 \mathrm{~b}$ shows microphotographs of the radial section and Figure 1 $\mathrm{c}$ shows the cross-section of Kielmeyera coriacea cork. Comparing these figures, the aspects of the transversal and radial sections are quite similar. For this reason, it was used the term non-tangential section to designate any of these sections (FORTES et al., 2004).

Cork cells in non-tangential section of Kielmeyera coriacea and Quercus suber, can be compared to rectangles with corrugated cell walls. Although the shape of the cells is rectangular, topologically they contain a number of sides (and vertices) which is not always equal to four (PEREIRA et al., 1987). The walls corrugation may arise from compression stresses that occur during cork formation, where a newly formed cell layer 'pushes' the existing cork cells into the outer part of the trunk. These corrugations play an important role in the mechanical behavior of cork material. According to Fortes et al. (2004) heavily corrugated cork cells are usually thin-walled and present low mechanical strength; therefore, less corrugated cells account for better mechanical properties.

Figure 2 shows photomicrographs of cork from Kielmeyera coriacea, displaying the counting of sides for each cell in tangential (Figure 2a) and non-tangential (Figure 2b) sections.

Table 1 presents the distribution function obtained in a tangential section of Kielmeyera coriacea cork (Figure 2), and compares this to the distribution of Quercus suber cork, from Fortes et al. (2004). Figure 2a shows that the number of sides of the polygons can vary,

Cerne, Lavras, v. 17, n. 3, p. 387-392, jul./set. 2011 

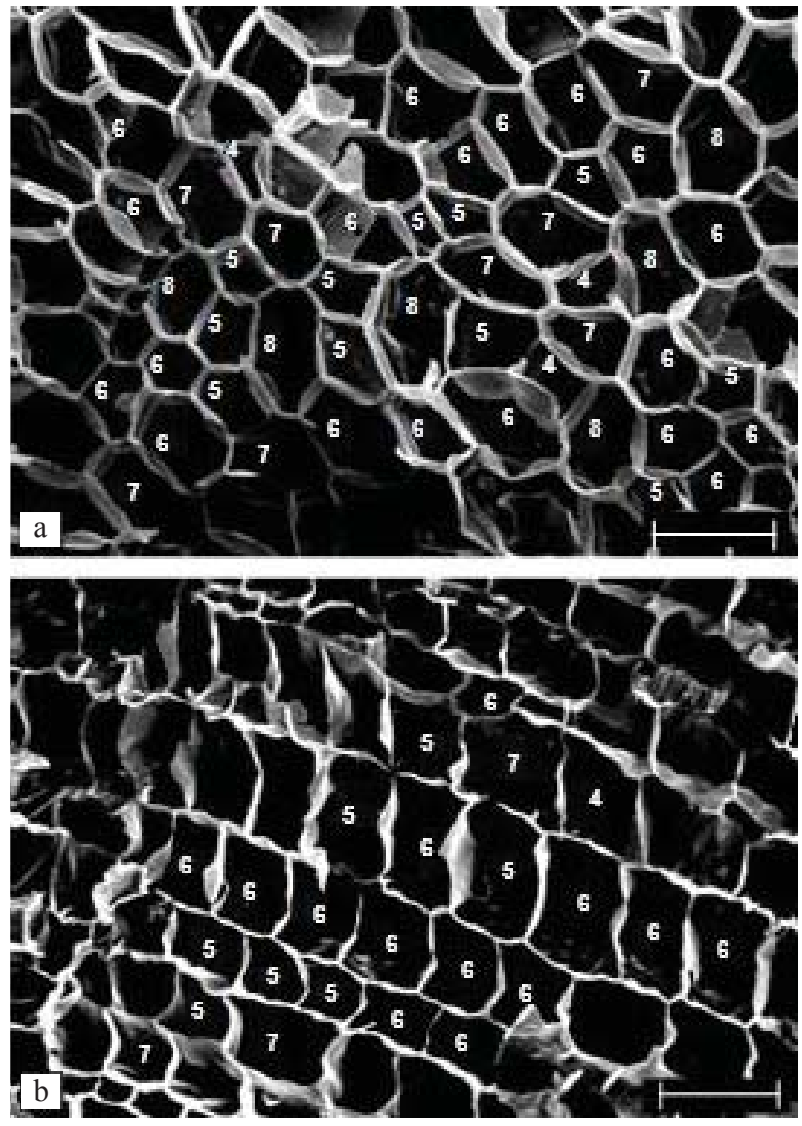

Figure 2 - Distribution of polygonal structure of Kielmeyera coriacea Mart. ("pau-santo") cork. (a) Tangential section shows the number of vertices of each cell, and (b) non-tangential section of cork shows the number of sides (vertices) of each cell. Scales: (a) and (b) $100 \mu \mathrm{m}$.

Figura 2 - Distribuição da poligonalidade da cortiça de Kielmeyera coriacea Mart. (pau-santo). (a) Seção tangencial com indicação do número de vértices de cada célula e (b) seção não-tangencial da cortiça com indicação do número de lados (vértices) de cada célula. Escalas: (a) e (b) $100 \mu \mathrm{m}$.

and the observation and counting of several cork specimens showed that, in this section, the number of sides ranged from 4 to 8 . However, most of the cells were observed to have 5 to 7 sides, accounting for about $80 \%$ of the total number of cells (the average number of sides $i$ was 6). These values are similar to those reported by Fortes et al. (2004) and Pereira et al. (1987) for Quercus suber, with the number of sides in the polygons from 4 to 9 and most of the cells having 5 to 7 sides. Also, for Quercus suber, Natividade (1950) reported a distribution from 4 to 8 , or rarely higher number of sides.

Cerne, Lavras, v. 17, n. 3, p. 387-392, jul./set. 2011
Table 1 - Comparison of the average distribution function in tangential section of cork from Kielmeyera coriacea and Quercus suber.

Tabela 1 - Comparação da distribuição média de poligonalidades na seção tangencial da cortiça de Kielmeyera coriacea e Quercus suber.

\begin{tabular}{ccc}
\hline$N_{i}$ & $f_{i}$ (Kielmeyera coriacea) & $f_{i}(\text { Quercus suber })^{*}$ \\
\hline $\mathrm{f}_{4}$ & 0.06 & 0.07 \\
$\mathrm{f}_{5}$ & 0.23 & 0.25 \\
$\mathrm{f}_{6}$ & 0.40 & 0.38 \\
$\mathrm{f}_{7}$ & 0.17 & 0.24 \\
$\mathrm{f}_{8}$ & 0.13 & 0.06 \\
$\mathrm{f}_{9}$ & 0.00 & 0.01 \\
\hline Total & 1 & 1 \\
\hline
\end{tabular}

$f_{i}$ : fraction of i-sided polygons; $N_{i}$ : Number of $i$-sided cells * Fortes et al. (2004).

For Kielmeyera coriacea the $\mu_{2}$ value was of 0.79 for the tangential section. Pereira et al. (1987), studied Quercus suber and reported $\mu_{2}$ of 0.71 for the tangential section of cork. This relatively low value obtained for $\mu_{2}$ reflects the low dispersion of $i$ values (between 4 and 8), with a predominance of 5, 6 and 7 sides. According to these results for the tangential section, one can infer that the cork cell walls are arranged randomly, indicating the absence of any favored orientation of the walls side. This was also observed and explained by Fortes et al. (2004) and Graça and Pereira (2004) for Quercus suber, in which cells of the same 'column' are generated one after another from the same phellogen cell.

Thus, in general, cork cells from the tangential section of Kielmeyera coriacea can be described as hexagonal prisms similar to those from the cork of Quercus suber as described by Pereira and Thomas (2004). This cellular structure, in practice, imparts some relevant and desirable properties such as elasticity and acoustics.

Figure $2 \mathrm{~b}$ shows that for non-tangential section, the number of sides of each cell is also variable, and observations made using several specimens of cork showed that the number of sides ranged from 4 to 7 .

Table 2 shows the typical distribution function of the non-tangential sections of cork. A comparison between the results of tangential and non-tangential sections indicates that, despite being very different in terms of topological types, both cork main sections are alike, with similar distribution values. 
Table 2 - Comparison of the average distribution function of non-tangential section of cork from Kielmeyera coriacea and Quercus suber.

Tabela 2 - Comparação da distribuição média de poligonalidades na seção não-tangencial da cortiça de Kielmeyera coriacea e Quercus suber.

\begin{tabular}{ccc}
\hline$N_{i}$ & $f_{i}($ Kielmeyera coriacea $)$ & $f_{i}(\text { Quercus suber })^{*}$ \\
\hline $\mathrm{f}_{4}$ & 0.04 & 0.02 \\
$\mathrm{f}_{5}$ & 0.291 & 0.22 \\
$\mathrm{f}_{6}$ & 0.54 & 0.53 \\
$\mathrm{f}_{7}$ & 0.13 & 0.18 \\
$\mathrm{f}_{8}$ & 0 & 0.04 \\
$\mathrm{f}_{9}$ & 0 & 0.01 \\
\hline Total & 1 & 1
\end{tabular}

$f_{i}$ : fraction of i-sided polygons; $N_{i}$ : Number of $i$-sided cells

* Fortes et al. (2004).

The $\mu_{2}$ value for non-tangential section of Kielmeyera coriacea cork was 0.58 . This result also indicates a low dispersion of $i$ sides (between 4 and 7), with a predominance of 5 and 6 sides. These values are similar to those reported by Fortes et al. (2004) for Quercus suber, with a distribution ranging from 4 to 8 and predominance of pentagonal and hexagonal cells. Thus, as discussed for tangential section, the distribution function of cork cells in non-tangential section is also random and independently generated by the phellogen cells.

Table 3 presents the averages of height and thickness (cellular wall) measured from Kielmeyera coriacea cork cells and compared to Quercus suber. According to Fortes et al. (2004) and Natividade (1950), the height and thickness of cell walls cork are classified according to two types: spring and autumn cells. The averages obtained from this study resembled those taken from Quercus suber spring cork reported by Fortes et al. (2004).

Table 3 - Dimensions of cork cells from Kielmeyera coriacea and boiled soft cork Quercus suber.

Tabela 3 - Dimensões das células da cortiça de Kielmeyera coriacea e da cortiça macia cozida de Quercus suber.

\begin{tabular}{lcc}
\hline Species & $\begin{array}{c}\text { Average height } \\
(\mu \mathrm{m})\end{array}$ & $\begin{array}{c}\text { Average thickness } \\
(\mu \mathrm{m})\end{array}$ \\
\hline Kielmeyera coriacea & $\begin{array}{c}40-70 \\
(20.85)^{* *}\end{array}$ & $1,5-2,0(0.41)^{* *}$ \\
$\begin{array}{l}\text { Quercus suber } * \\
\text { (spring cells) }\end{array}$ & $30-40$ & $1-1.5$ \\
\hline
\end{tabular}

* Fortes et al. (2004)** Standard deviation
Natividade (1950) states that the heights of Quercus suber cork cells, in general, differ widely with values barely exceeding $70 \mu \mathrm{m}$ for spring cells, and below $10 \mu \mathrm{m}$ for cells from the late season (autumn cells). Fortes et al. (2004) affirm that the cells from the early season (spring cells) are more elongated and have an approximate height of 30 to $40 \mu \mathrm{m}$; while cell wall thickness lies between 1 and $1.5 \mu \mathrm{m}$. On the other hand, the cells of the late season cork are narrower with heights of approximately 10 to 15 $\mu \mathrm{m}$, and wall thickness between 2 to $3 \mu \mathrm{m}$. Fortes (2001) also comments on the variable average height of cork cells, indicating 15 to $20 \mu \mathrm{m}$ height for spring cells and 30 to $40 \mu \mathrm{m}$ for spring cells.

The greater values of heights and similar values of wall thickness obtained for the cork cells from Kielmeyera coriacea, when compared to the "soft" cork (cork generated after successive extractions) from Quercus suber, can be explained because the lower compression stress that arises during the formation of Kielmeyera coriacea cork. Considering the height of a mature tree of Kielmeyera coriacea, 1 to $4 \mathrm{~m}$, and thin trunk (6 to $8 \mathrm{~cm}$ in diameter), when compared to an adult tree of Quercus suber of 10 to $15 \mathrm{~m}$ and thick trunk, the latter probably has a greater growth tension during its development, resulting in smaller average cell height and strongly corrugated walls. Graça and Pereira (2004), Payne and Thomas (2004) and Pereira et al. (1987), also refer to the corrugations of the side walls as a result of compression during the growth of the cork.

Even under industrial processing (heating) which the "soft" cork of Quercus suber is submitted, aiming to induce a low value of cell wall corrugation amplitude (PEREIRA, 2007), cork cells from Kielmeyera coriacea exhibited greater cellular heights without any treatment. From a technological point of view, the cork of Kielmeyera coriacea may offer a good quality material, since it does not present strong corrugations, and consequently might present high mechanical strength.

\section{CONCLUSIONS}

According to the distribution of polygonal sides, height, and thickness of cork cells, it can be concluded that cork cells from Kielmeyera coriacea were quite similar to those from Quercus suber.

Similar to Quercus suber, the distribution of polygonal sides found in Kielmeyera coriacea was between 4 and 8 , and 6 was the predominant number of sides.

Cerne, Lavras, v. 17, n. 3, p. 387-392, jul./set. 2011 
The results of cork cell wall height and thickness ranged from 40 to $70 \mu \mathrm{m}$ and 1.5 to 2.0 micrometers, respectively, the latter indicating early season cells. Both height and thickness showed higher values when compared to Quercus suber.

\section{ACKNOWLEDEGEMENTS}

The authors would like to express their thanks to professor Dr. Eduardo Alves from the Departamento de Fitopatologia/Universidade Federal de Lavras, for his support during the electron microscopic analyses. Special thanks to professors Dr. José A. R. Graça and Dr. Teresa Quilhó from the Departamento de Engenharia Florestal/ Universidade Técnica de Lisboa, for enriching this work with their remarkable advice.

\section{REFERENCES}

AGRO.GES. O sobreiro e a cortiça. Lisboa, 2000.

DIONELLO, S. B.; BASTA, F. Informações sobre os caracteres quantitativos e qualitativos dos frutos e sementes de Kielmeyera coriacea Mart. Brasil Florestal, Rio de Janeiro, v. 58, p. 25-30, 1980.

FERREIRA, M. B. Flores do planalto: divisas para Brasília. Brasília: Cerrado, 1974. 23 p.

FORTES, M. A. A cortiça. Lisboa: IST, 2001. 25 p.

FORTES, M. A.; ROSA, M. E.; PEREIRA, H. A cortiça. Lisboa: IST, 2004. 259 p.

Cerne, Lavras, v. 17, n. 3, p. 387-392, jul./set. 2011
GRAÇA, J.; PEREIRA, H. The periderm development in Quercus suber L. IAWA Bulletin, Leide, n. 25, p. 325-335, 2004.

GRAMACHO, R. S. Estudo químico do caule de Kielmeyera elata e aplicações biológicas de seus constituintes químicos. 1997. 147 f. Dissertação (Mestrado em Agroquímica) Universidade Federal de Viçosa, Viçosa, 1997.

LIMA, J. T.; MARCATI, C. R. Anatomia da madeira de Kielmeyera coriacea Mart. (Pau-santo) - Guttiferae. In: CONGRESSO NACIONAL DE BOTÂNICA, 40., 1989, Cuiabá. Resumos... Cuiabá, 1989. p. 301.

NATIVIDADE, J. V. Subericultura. Lisboa: Ministério da Economia, Direção Geral dos Serviços Florestais e Aquícolas, 1950. 387 p.

PEREIRA, H. Cork: biology, production and uses. New York: Elsevier, 2007.

PEREIRA, H.; ROSA, M. E.; FORTES, M. A. The cellular structure of cork from Quercus suber L. IAWA Bulletin, Leiden, v. 8, n. 3, p. 213-217, 1987.

PEREIRA, H.; TOMÉ, M. Cork oak and cork: encyclopedia of forest sciences. Oxford: Elsevier, 2004. 620 p.

RIZZINI, C. T.; HERING, E. P. Preliminares acerca das formações vegetais e reflorestamento no Brasil Central. Rio de Janeiro: Secretaria de Agricultura, 1962.

SOUZA, F. P. Tecnologia de produtos florestais. Rio de Janeiro: Nacional, 1974. 409 p. 